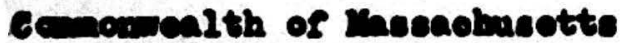 Departanat of Publie Warke John A. Volpe, Cendericacer}

J. 8. Departenent of the Intorior ceologleal surver

W. Bo Wrathor. Dirvotor

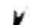
Cocperatio Geologlo Projeet

\title{
I110 Ropart
}

Geologie and 8o1ende Investigations

for Roloonticn of Route 128 at Route is

in Dedher, Naee.

by

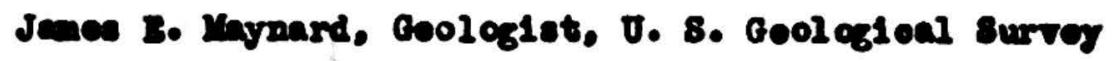

2 pages of teat

4 plater

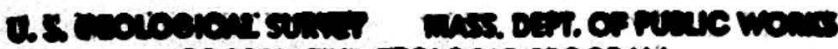
cocrinatue govesic moenu OVEN FUI RENORT
Boetca, rascacluseotta

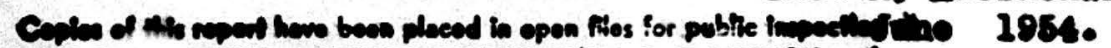

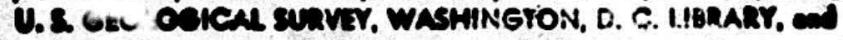

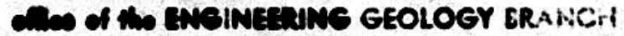
U. CeOLOGical sulvit, 270 Dartmouth Streot. Saluate sorioe *

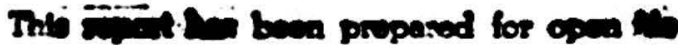
enty, and hes not been oditsd tre coniorum - i. I. Cheologioal Survey siandand ard i. astara. 


\section{Goolegie and solente Invortigatione \\ for Rolooution of Route 128 at Route is \\ In Dedhan, Nase.}

by

Janes B. Naynard, Goologlet, 0. 8. Geologieal Survey

Goneral Statement

The proposed reloonti on of Routo 128 in Dedham, Mass. regulres a grade eoparation with long appronoh oute at its oroseing with Route 14 . In ardor to obtaln infaration on the ocnfiguration and dopthe of the bedrook surfeoes, and on the nature of tho overlying natorial, a goologle study was ade of tho 1te, and a progran of solenis work was earried out. Tho work wa performed In Jume. Auguet and septeabor 1058 as part of a cocporative program of tho Maseachusetts Dopartmont of Publie Woris and tho United Staten Goologleal Surver.

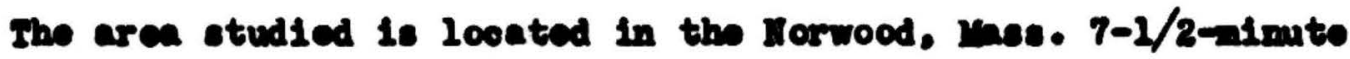
quadrangle map of the Onited 8tates Geologieal Survy.

Ir. Y. I. Chandler and Mr. W. I. Carnoy, Departanent of Publ1e Norke" Figlecere, perfored all portincent eurver work required for this projeot, and prepared the essential plene and proflles. Yr. Chandler also eperated

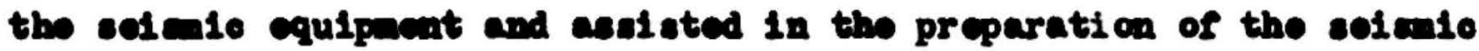
roloeity daten.

\section{Surface Goolew}

This of to coeurs at the interseotica of Routes in and 128 on the uppor boundary botween a kane torrace and an undulatory t11l-bedroak upland. In 
general, cast of Route 14 , the ourfaoe formation is largely cands weat of Routo in 1t 1s mostiy till that in tho vieinity of tho boundary 1s very sandy. Construetion of roade and buildinge, and the grading of this our freos of the land ade 1t diffioult to eatablich the eandotill boumdary without difging numorous teet pite; consequently tho boundary 1e not shown on the plem. Hunorou exposures of granltie bedrook coeur in the till arcae, but none were noted in the sand arcas. In genoral, bedrook appeare to bo at a shallen dopth at thie alto.

\section{Solende Ireverses}

81xteon solenis traverses were ande at thle alto. Tho looaticen of the shot pointe and the arrangencat of the 1 ines are shom on ehcote 1 and 2.

\section{Bubeurface Interretation}

The geolog10 cootione an Intorpreted fron the eurface gool ogy and the

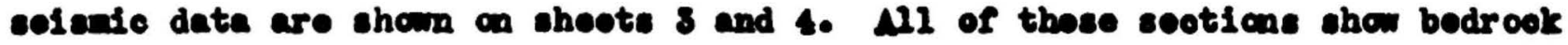
at relatively shallew dopths, \& to 25 foot bolow the surface of the ground. The bedrook profiles as shown on the scotione represent only a goneralleation

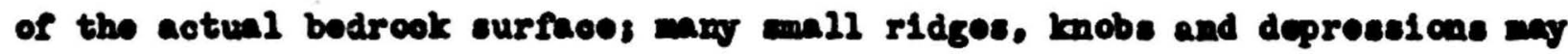
oocur at altitudes ellghtly above and bolow thoee profilea. In gonoral, a resy irregular and undulatory bedroek surface can be expeotod at the elto. 


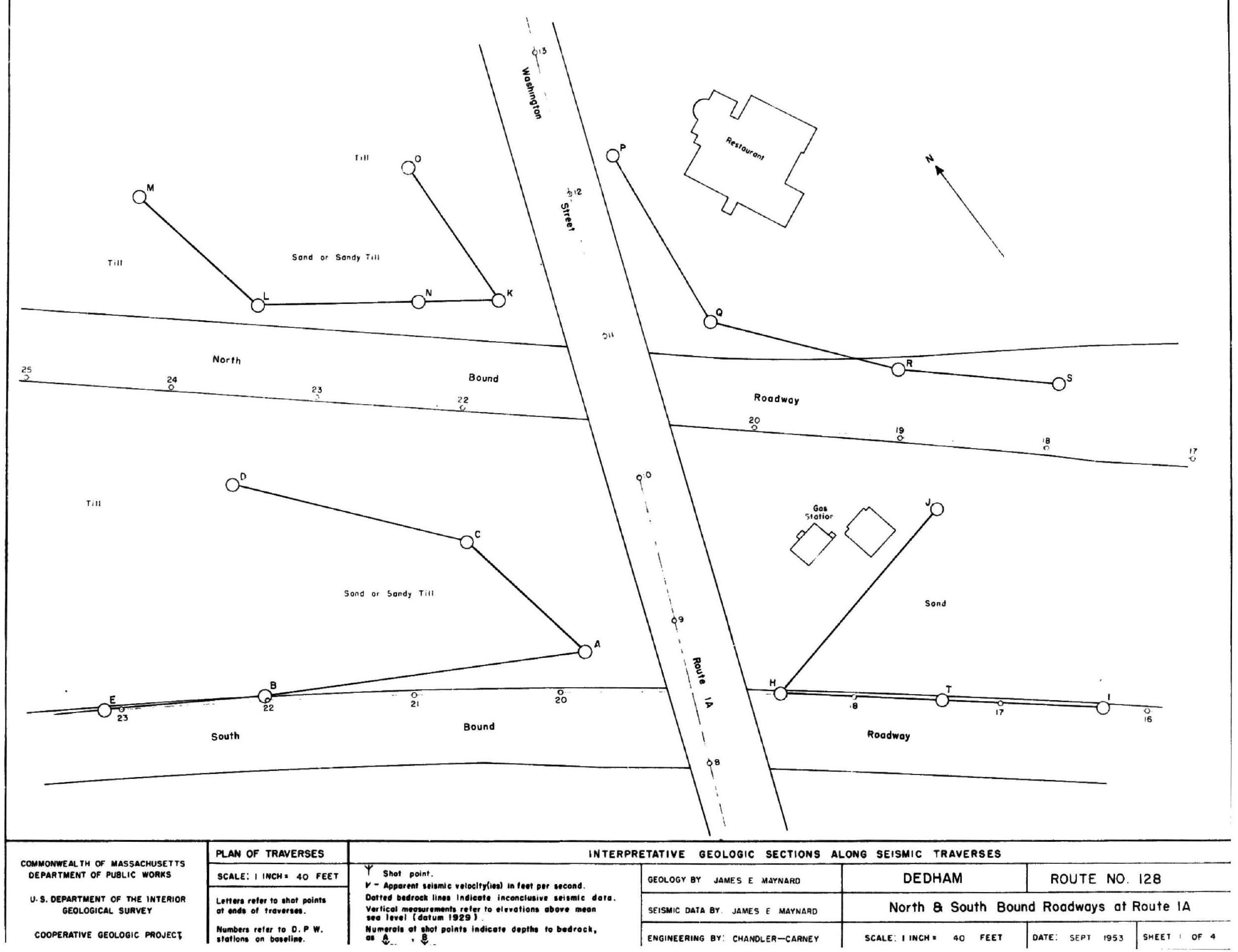




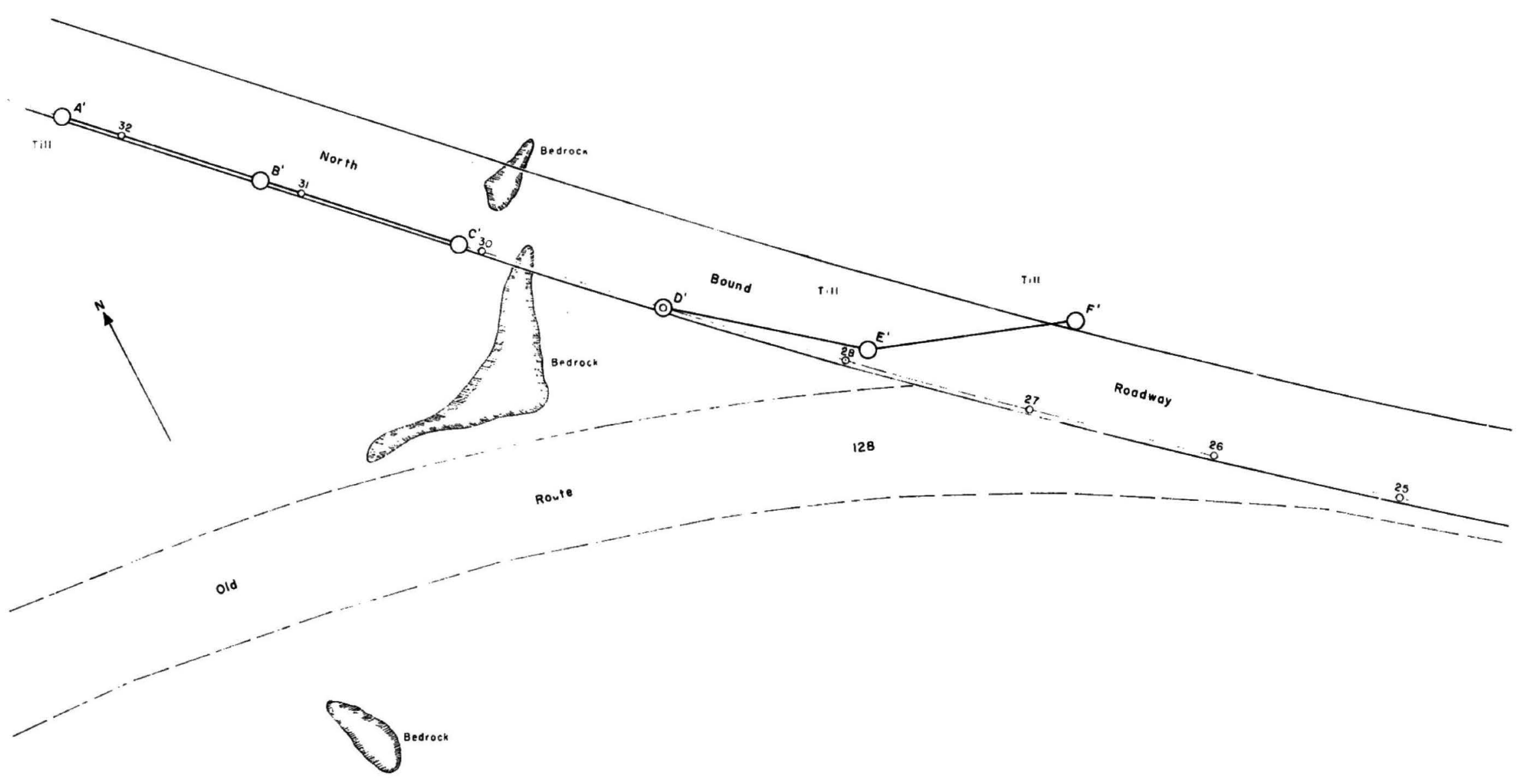

TIII

30

29

$0 \%$

South

27

Bound

-

${ }_{26} \cdots \mathrm{O}_{25}^{\mathrm{C}}$

Roodwoy

Till

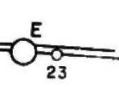

Till

COMMONWEALTH OF MASSACHUSETTS DEPARTMENT OF PUBLIC WORKS

U. S. DEPARTMENT OF THE INTERIOR Geological SURVEY

COOPERATIVE GEOLOGIC PROJECT

\begin{tabular}{l} 
PLAN OF TRAVERSES \\
\hline SCALE: I INCH : 40 FEET \\
\hline Letrors reter to shot points \\
at ends of troverses. \\
Numbers reter to O.P w. \\
stoflions on boseline.
\end{tabular}

Numbers reter to O.P w.

\section{INTERPRETATIVE GEOLOGIC SECTIONS ALONG SEISMIC TRAVERSES}

$Y$ Shot point
$v$ - Apporent seismic volocityfies) in foet per second. Dotted bedrock lines indicete inconclusive seismic date. verticeal megesurementer ferter to elevolions above meon Numerals ot athot points indicate oeptre to bedrock, Numerols of thot

\begin{tabular}{|c|c|c|c|c|}
\hline GEOLOGY QY JAMES E. MAYNARO & DEDHAM & & ROUTE NO & 128 \\
\hline SEISMIC DATA BY. JAMES E. MAYNARO & \multicolumn{4}{|c|}{ North $\&$ South Bound Roadways at Route IA } \\
\hline ENGINEERING OY. CHANOLER-CARNEY & SCALE I INCH = 40 & FEET & OATE: SEPT 1953 & SHEET 2 OF 4 \\
\hline
\end{tabular}



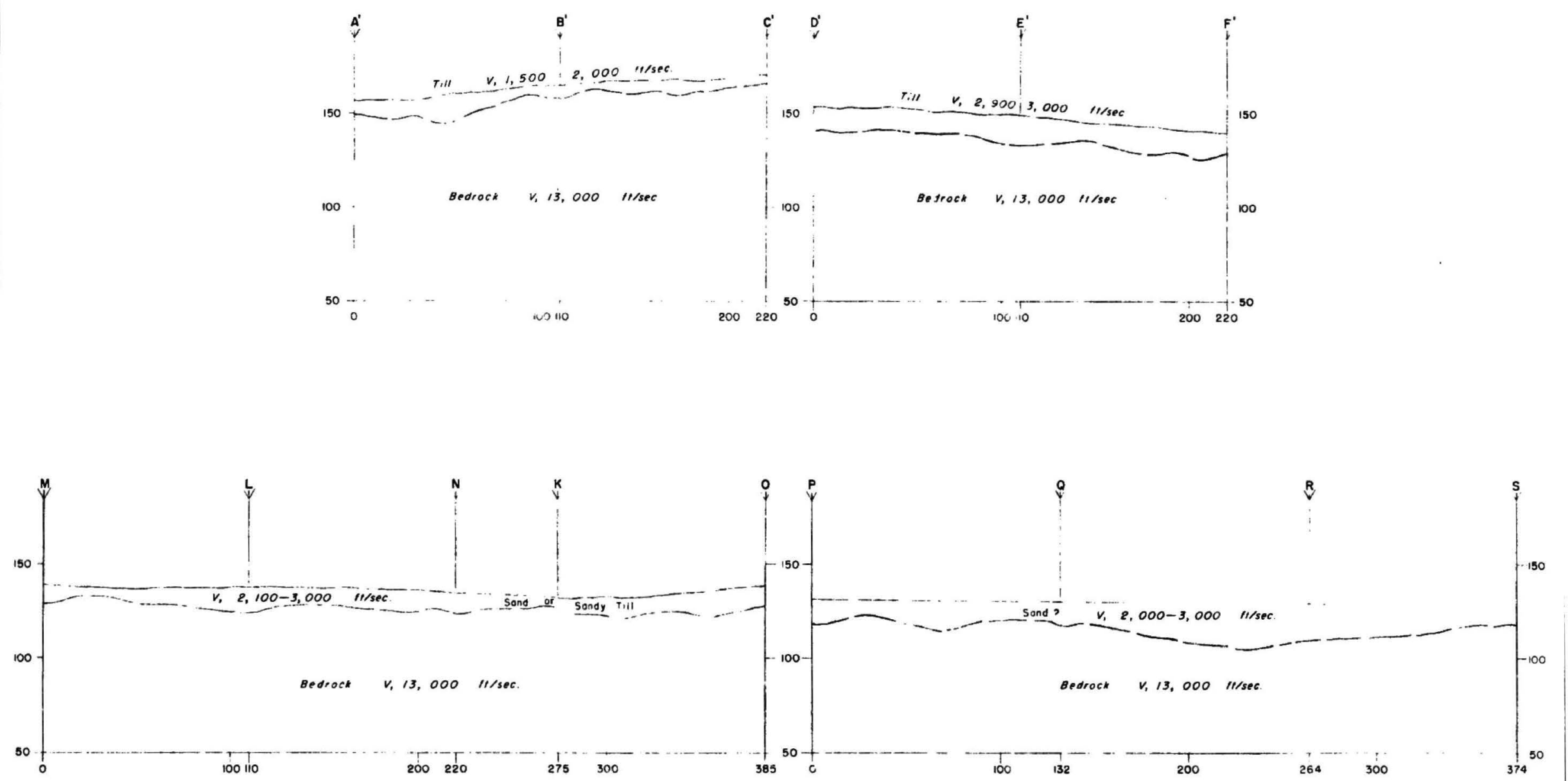

COMMONWEAL TH OF MASSACHUSETTS
DEPARTMENT OF PUBLIC WORKS
U.S. DEPARTMENT OF TME INTERIOR
COOPERATIVE GEOLOGIC PROJECT

CoOperative geologic PRoJect

\begin{tabular}{|c|c|}
\hline PLAN OF TRAVERSES & INTERP \\
\hline SCALE: I INCH = 40 FEET & \\
\hline 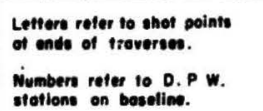 & 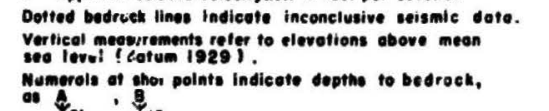 \\
\hline
\end{tabular}

INTERPRETATIVE GEOLOGIC SECTIONS ALONG SEISMIC TRAVERSES

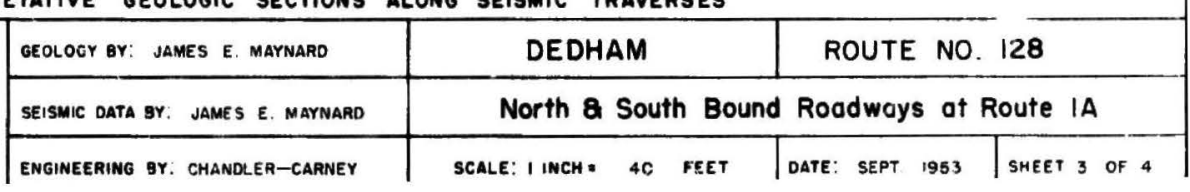



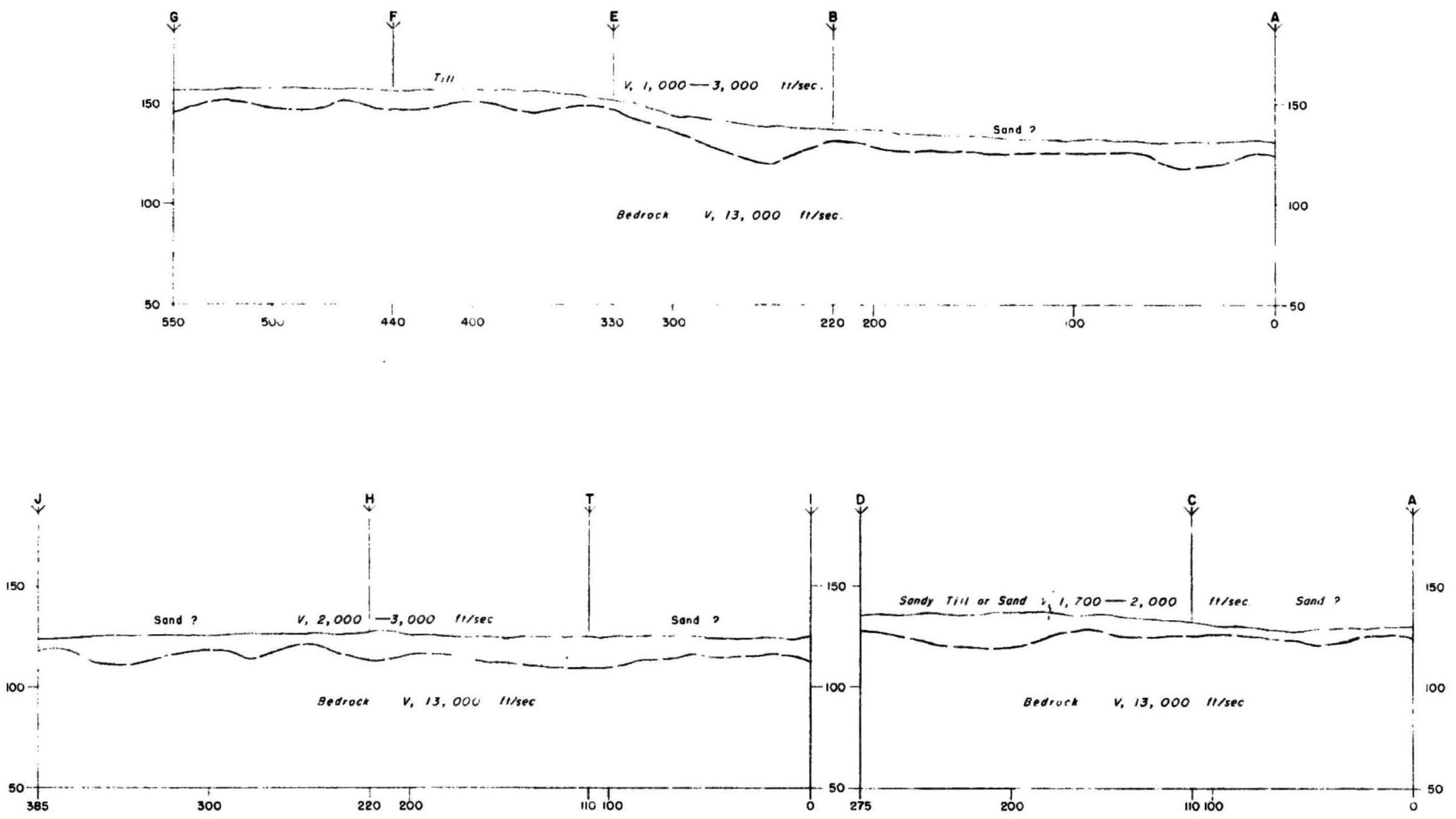

$\Psi$ Shot point.

$v$ - Apporent seismic velochyliest in feet por second. Dotted bedroek lines Indicate inconclusive seismic date. Verticol moovurementy refer to elevolions above meen

Numerols at ehet points indicate depths to bedrock.

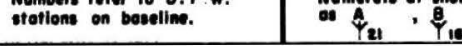

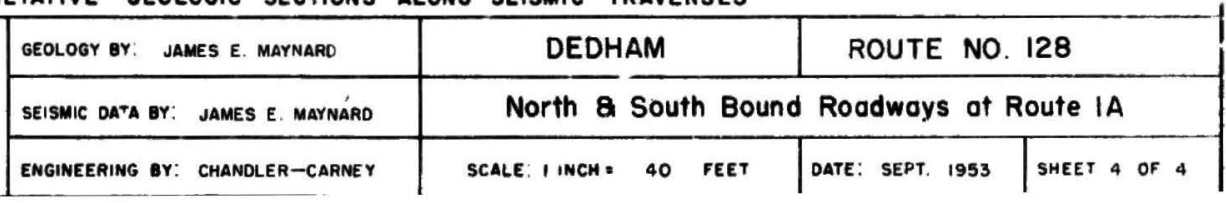

